\title{
Implementasi Perencanaan Pondok Pesantren dalam Meningkatkan Kualitas Santri
}

\author{
Eko Rahmad Cahyono*, Aliyudin ${ }^{1}$, Herman $^{2}$ \\ ${ }^{1}$ Jurusan Pengembangan Masyarakat Islam, Fakultas Dakwah dan Komunikasi, UIN Sunan \\ Gunung Djati, Bandung \\ 2Jurusan Manajemen Dakwah, Fakultas Dakwah dan Komunikasi, UIN Sunan Gunung Djati, \\ Bandung \\ *Email : eko.squad123@gmail.com
}

\begin{abstract}
ABSTRAK
Tujuan dilakukannya penelitian ini adalah untuk mengetahui penetapan tujuan, pemrograman dan penganggaran kegiatan Pondok Pesantren At-Tamur untuk menciptakan generasi santri yang diinginkan oleh pondok pesantren agar mengembangkan kualitas santri untuk bisa berkembang di masyarakat dan bermanfaat untuk masyarakat. Penelitian ini menggunakan metode deskriptif yang menghasilkan data berupa perkataan yang tertulis maupun lisan dari sumber-sumber penelitian. Teknik pengumpulan datanya adalah deduktif empirik melalui kegiatan observasi, wawancara dan dokumentasi. Dari hasil penelitian ini ditemukan bahwa untuk meningkatkan kualitas para santri dalam bidang keagamaan, keilmuan, kewirausahaan, dan sosial. Untuk meningkatkan pelajaran agama, baik dari segi akhlak, dan ibadah. Kemudian dilengkapi dengan program Pondok Pesantren At-Tamur berupa; prgram mengaji Al-Qur'an, hadits, kitab kuning, praktek ibadah mahdhoh dan ghairu mahdhoh, belajar akhlak, kegiatan belajar mengajar. Dalam bidang penganggaran kegiatan di Pondok Pesantren At-Tamur berbeda dengan lembaga lainnya yaitu dengan sumber donatur dan relawan.
\end{abstract}

Kata kunci: Implementasi; Perencanaan; Pesantren; Kualitas; Santri.

\section{ABSTRACT}

The purpose of this research is to determine the goal setting, programming and budgeting of the At-Tamur Islamic Boarding School activities to create the generation of students desired by Islamic boarding schools to develop the quality of students to be able to develop in society and be beneficial to society. The method used in this research is descriptive method that produces descriptive data in the form of written and oral words from research sources with the data collection technique is empirical deductive through ovservation, interviews and 
E. R. Cahyono, Aliyudin, Herman

documentation. From the results of this study namely to improve the quality of students in the fields of religion, science, entrepreneurship, and social. To improve, religious studies, both in terms of morals, and worship. Then it is complemented by the At-Tamur Islamic Boarding School program of the Qur'an study program, hadith, yellow book, mahdhoh and ghairu mabdhoh worship practices, moral learning, teaching teaching activities. In the field of budgeting the activities at At-Tamur Islamic Boarding School are different from other institutions, namely from donorss and volunteer sources.

Keywords: Implementation; Planning; Islamic Boarding School; Quality; Santri.

\section{PENDAHULUAN}

Pada dasarnya setiap perusaaan ataupun lembaga pasti memiliki sebuah manajemen yang berfungsi untuk menjalankan sebuah pekerjaan agar mencapai tujuan perusahaan ataupun lembaga tersebut. Manajemen menjadi inti dari sebuah perusaaan ataupun lembaga yang memiliki sebuah tujuan-tujuan yang sudah menjadi acuan untuk masa sekarang ataupun masa yang akan datang. Di dalam manajemen tentu ada sebuah perencanaan yang merupakan hasil rangkaian kerja suatu perusahaan ataupun lembaga untuk mendapatkan apa yang akan ditinjau pada masa yang akan datang. Maka dari itu manajemen sesuatu yang menjadikan sebuah tujuan ataupun rangkaian sebuah cita-cita yang memiliki proses pada sebuah perusahaan maupun lembaga.

Perencanaan merupakan salah satu fungsi manajemen yang penting dan saling terkait satu sama lain. Menurut G.R Terry yang dikutip oleh Hasibuan (2006: 92) menyatakan bahwa:

Planing is the selecting and relating of facts and the making and using of assumptions regarding the future in the visualization and formulation of proposed activitions believed necessary to achieve desired results. (Perencanaan adalah memilih dan menghubungkan fakta dan membuat serta menggunakan asumsi-asumsi mengenai masa datang dengan jalan menggambarkan dan merumuskan kegiatan-kegiatan yang diperlukan untuk mencapai hasil yang diinginkan).

Dalam surat Al-Hasyr ayat 18, Allah berfirman:

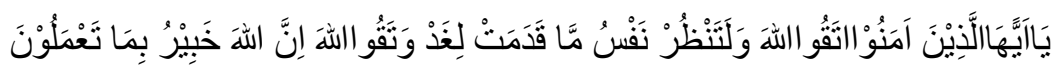

Artinya: Hai orang-orang yang beriman, bertakwalah kepada Allah dan hendaklah setiap diri memperhatikan apa yang telah diperbuatnya untuk hari esok dan bertakwalah kepada Allah, sesunggubnya Allah Maha Mengetahui apa yang kamu kerjakan.

Maqoddamat ligod yang artinya memeperhatikan apa yang telah dilakukan untuk hari esok pada firman Allah tersebut dapat kita tafsirkan dan kita buktikan bahwa Al-Quran telah memperkenalkan teori perencanaan baik berkaitan dengan perencanaan dalam kehidupan di dunia maupun untuk kehidupan di akhirat. 
Pesantren merupakan media dan lembaga dakwah Isalm di Indonesia didirikan karena adanya tuntutan dan kebutuhan zaman. Sistem pendidikan Islam Indonesia di dirikan yang dikembangkan dapat dilihat dari dua orientasi. Pertama, berorientasi terhadap penguatan basis keagamaan bagi masyarakat muslim. Kedua, sebagai media konsultasi dan sosialisasi terhadap masyarakat nusantara yang belum sepenuhnya menganut agama Islam (Alkhairy, 2017: 58).

Pesantren merupakan lembaga pendidikan Islam yang memenuhi syarat dan ketentuan kelembagaan pesantren di Indonesia berdasarkan hasil survey Administrasi Kementrian Agama Republik Indonesia. Dengan berkembangnya zaman pondok pesantren tidak lagi menggunakan bambu sebagai tempat tinggal dan mampu menyeimbangi dengan perkembangan zaman. Dalam pengorganisasian, pondok pesantren tentu memiliki rencana baik dalam pengembangan inprastruktur sistem, dan lain sebagainya. Mengembangkan pondok pesantren tidak hanya sebatas SDA saja, melainkan SDM juga perlu dikembangkan baik itu dari kalangan gurunya maupun dari kalangan para santri agar mampu bersaing dengan lembaga pendidikan yang lainnya.

Pondok Pesantren Anak Jalanan At-Tamur adalah salah satu pondok pesantren yang ada di Kabupaten Bandung khususnya di Cibiruhilir, yaitu pesantren yang ada dikhususkan untuk anak jalanan, orang-orang yang kurang mampu baik dari segi ekonomi maupun agama, supir angkot, pengamen, dan lain sebagainya. Namun Pondok Pesantren At-Tamur tidak hanya anak yang berusia sebagaimana anak pada umumnya, melainkan siapa saja yang hendak belajar mengaji, tidak dibatasi dengan usia. Pondok Pesantren Anak Jalanan At-Tamur ini diresmikan bersama anak jalanan, anak terlantar, sopir angkot, kendek, tukang parkir, pengamen, eks narkoba, eks narapabidana, dan anak-anak yang berasal dari keluarga tidak mampu baik di pandang dari sisi ekonomi, pendidikan agama maupun pendidikan formal (Profil Pondok Pesantren At-Tamur). Pondok Pesantren Anak Jalan At-Tamur yang memiliki tujuan yang mulia yaitu membimbing santri untuk bisa menuju jalan Allah yang diperintakan dan diajarkan oleh Nabi menuju jalan yang lebih baik dan yang diridhoi-Nya. Mengelola santri yang berlatar belakang anak jalanan bukanlah hal yang mudah untuk merubah perilaku santri yang asalnya radikal tentu memiliki tantangan yang luar biasa. Dalam pengamatan peneliti bahwasannya Pondok Pesantren Anak Jalanan At-Tamur mempunyai perencanaan yang cukup bagus dalam membimbing santri.

Pada penelitian terdahulu yang dilakukan oleh Hasan Munawa pada tahun 2017 yang berjudul Perencanaan Pondok Pesantren Dalam Membentuk Kader Ulama. Penelitian ini menemukan bahwa aspek menentukan tujuan di Pesantren Wahdatut Tauhid bertujuan untuk membentuk kader ulama, dalam mencetak imamal muttaqin, dan sholihin. Aspek menentukan kebijakan di Pesantren Wahdatut Tauhid lebih kepada perjanjian antara pihak orang tua santri dengan 
pihak pesantren. Aspek menentukan prosedur di Pondok Pesantren Wahdatut Tauhid meliputi empat bagian, antara lain: kelas Ibtida (selama 3 tahun), kelas Tsanawy (selama 3 tahun), kelas Ma'had Aly (selama 2 tahun), dan pengabdian (selama 1 tahun). Aspek menentukan program di Pondok Pesantren Wahdatut Tauhid bertujuan menciptakan kader-kader dai dan juga ulama dimasa yang akan datang. Dalam menciptakan semua ini maka diajarkan ilmu-ilmu yang berhubungan dengan keislaman seperti ilmu fiqih, tauhid, akhlak, bahasa dan keilmuan lainnya.

Penelitian ini dilakukan di Pondok Pesantren At-Tamur Jl. Cibiru Hilir No. 04 RT/RW 01/01 Desa Cinunuk Hilir Kecamatan Cileunyi Kabupaten Bandung Jawa Barat Indonesia. Dengan metode yang digunakan dalam penelitian ini adalah metode deskriptif yaitu prosedur penelitian kualitatif yang menghasilkan data deskriptif berupa perkataan yang tertulis maupun lisan dari sumber-sumber penelitian dan perilaku yang dapat diamati. (Muh, Fitrah dan Lutfhiyah, 2017: 44)

Dengan metode ini peneliti bermaksud untuk mengetahui lebih lanjut mengenai implementasi perencanaan pondok pesantren dalam pengembangan kualitas santri melalui observasi. Wawancara dan komunikasi dalam perolehan data yang akurat dan benar secara sistematis.

\section{LANDASAN TEORITIS}

Dalam penelitian ini, penulis kemukakan pengertian dengan teori Implementasi, Perencanaan, Penetapan Tujuan, Pemrograman, Penganggaran, Pesantren, Kualitas dan Santri. Pertama, pengertian implementasi Secara etimologis pengertian implementasi menurut Kamus Webster yang dikutip oleh Solichin Abdul Wahab adalah "Konsep implementasi berasal dari Bahasa Inggris yaitu to implement. Dalam Kamus Besar Webster, to implement (mengimplementasikan) berarti to provide the means for carrying out (untuk menimbulkan dampak/akibat terhadap sesuatu)" (Webster dalam Wahab, 2004: 64). Sesuatu tersebut dilakukan untuk menimbulkan dampak atau akibat itu dapat berupa undangundang, peraturan pemerintahan, keputusan pengadilan dan kebijakan yang dibuat oleh lembaga-lembaga pemerintah dalam kehidupan kenegaraan. (http://rimaru.web.id/pengertian-implementasi-menurut-beberapa-ahli/) (21.54.6/4/2019).

Sedangkan Van Meter dan Van Horm (1975), dalam bukunya Leo Agustino (2006: 139), mendefinisikan implementasi sebagai: "tindakan-tindakan yang dilakukan baik oleh individu-individu atau pejabat-pejabat atau kelompokkelompok pemerintah atau swasta yang diarahkan pada tercapainya tujuan-tujuan yang telah digariskan dalam keputusan kebijaksanaan". Secara sederhana implementasi bisa diartikan pelaksanaan atau penerapan. Majone dan Wildavsky (dalam Nurdin dan Usman, 2002), mengemukakan implementasi sebagai 
evaluasi.

Kedua, pengertian Perencanaan "Perencanaan disebut sebagai fungsi pertama dalam manajemen, perencaan juga diartikan sebagai proses dasar dimana manajemen memutuskan tujuan dan cara mencapainya" (Handoko, 2009: 77). Maksudnya adalah perencanaan merupakan suatu langkah awal dalam memulai suatu kegiatan yang akan datang dalam jarak dan waktu tertentu pelaksanaan kegiatan tersebut. Berhasil tidaknya suatu kegiatan yang dilaksanakan, tergantung pada awal dari merencanakan kegiatan tersebut. Perencanaan (Planning) merupakan pemilihan dan penghubung fakta dengan menggunakan asumsi-asumsi tentang masa depan dalam membuat visualisasi dan perumusan kegiatan yang diusulkan dan memang diperlukan untuk mencapai hasil yang diinginkan (G. R. Terry,1990). Perencanaan diartikan sebagai suatu kumpulan keputusan untuk mempersiapkan tindakan-tindakan dimasa mendatang (Widjajakusuma, 2002: 109).

Perencanaan (Siagian, 1989: 50) merupakan usaha sadar dan pengambilan keputusan yang telah diperhitungkan dengan matang tentang hal-hal yang akan dikerjakan dimasa depan dalam dan oleh suatu organisasi dalam rangka pencapaian tujuan yang telah ditetukan sebelumnya (Susilawati, 2016: 195).

Perencanaan dapat didefinisikan sebagai suatu proses menentukan sasaran yang ingin dicapai, tindakan yang seharusnya dilaksanakan, bentuk organisasi yang tepat untuk mencapainya dan SDM yang bertanggung jawab terhadap kegiatan-kegiatan yang akan dilakukan (M. Karebet w. Dan M. Ismail Yusanto, 2002: 109). Dalam perencanaan memiliki fungsi-fungsi perencanaan menurut Louis A. Allen yaitu (1) forecasting (peramalan), (2) establishing objectives (penetapan tujuan), (3) programming (pemrograman), (4) scheduling (penjadwalan), (5) budgeting (penganggaran), (6) developing procedure (pengembangan prosedur) dan, (7) establishing and interpreting policies (penetapan dan penafsiran kebijakan) ((Hasibuan, 2006: 113).

Ketiga, pengertian penetapan tujuan menurut Lumpkin dan Taylor tujuan yang baik memiliki kriteria-kriteria sebagai berikut; (1) dapat diukur (Measurable). Tujuan harus dapat diukur. Untuk dapat mengukur pencapaian tujuan, sekurangkurangnya terdapat satu indikator yang dapat dijadikan rujukan untuk melihat kemajuan pencapaian tujuan. (2) spesifik (Specific). Tujuan secara spesifik harus menjelaskan apa yang ingin dicapai oleh perusahaan. (3) sesuai (Appropriate). Tujuan yang ingin dicapai perusahaan harus sesuai dengan visi dan misi yang dimiliki oleh perusahaan, artinya tujuan yang ingin dicapai masih berada dalam lingkup misi perusahaan. (4) realistis (Realistic). Tujuan yang dibuat oleh perusahaan harus dapat dicapai dengan menggunakan sumber daya organisasi yang dimiliki perusahaan. (5) tepat waktu (Timely). Perusahaan harus menetapkan secara spesifik berapa lama jangka waktu yang dibutuhkan perusahaan untuk mencapai tujuan yang telah ditetapkan (Sholihin, 2012: 23). 
Keempat, pengertian pemrograman "Program adalah satu rencana yang pada dasarnya telah menggambarkan rencana yang konkret. Rencana ini konkret karena dalam program sudah tercantum baik sasaran, kebijaksanaan, prosedur, waktu maupun anggarannya. Jadi, program juga merupakan usaha-usaha untuk mengefektifkan rangkaian tindakan yang dilaksanakana menurut bidangnya masing-masing. Suatu rencana biasanya meliputi bidang-bidang produksi, finansial, personalia dan pemasaran yang masing-masing disusun dalam berbagai program dan setiap program ini harus saling menunjang pelaksanaan berbagai macam program itu. Programming adalah proses penyusunan suatu program, jadi programming sifatnya dinamis sedangkan program sifatnya statis" (Hasibuan, 2006: 95).

Kelima, pengertian penganggaran, Anggaran (budget) merupakan penerjemahan program ke dalam satuan numerik. Anggaran tidak akan dapat disusun dengan baik bila perusahaan tidak memiliki program yang jelas. Hal tersebut disebabkan karena setiap rupiah yang akan dikeluarkan dalam anggaran mengacu ke program yang akan dikerjakan oleh perusahaan (Sholihin, 2012: 31).

Menurut Smith (dalam Ismail Sholihin, 2012: 32) secara garis besar, anggaran yang disusun oleh perusahaan dapat dikelompokkan ke dalam dua kategori, yaitu (1) Master budget menunjukkan keseluruhan perencanaan perusahaan dalam satuan rumerik untuk suatu priode tertentu dan biasanya bersifat jangka pendek. (2) Capital budget merupakan budget yang disiapkan perusahaan apabila perusahaan membutuhkan investasi yang besar dalam jangka waktu pengembalian investasi yang panjang.

Keenam, pengertian pesantren secara terminologis, pesantren didefinisikan sebagai lembaga pendidikan tradisional Islam untuk mempelajari, memahami, mendalami, menghayati, dan mengamalkan ajaran Islam dengan menekankan pentingnya moral keagamaan sebagai pedoman perilaku sehari-hari (Damopolii, 2011: 58).

Zamakhsyari Dhofier mengutip beberapa pendapat para ahli tentang asalusul istilah pesantren, seperti pendapat Profesor Johns yang mengatakan bahwa istilah santri sebenarnya berasal dari bahasa Tmil, yang berarti guru mengaji. Sedangkan C.C. Berg berpendapat bahwa istilah tersebut berasal dari istilah shastri yang dalam bahasa India berarti orang yang tahu buku-buku suci agama Hindu, atau seorang sarjana ahli kitab suci agama Hindu. Selain itu, ada juga yang berpendapat bahwa kata shastri berasal dari kata shastra yang berarti buku-buku suci, buku-buku agama atau buku-buku tentang ilmu pengetahuan (Dhofier, 1994: 18.)

Ketujuh, pengertian kualitas "kata kualitas memiliki banyak definisi yang berbeda dan berpariasi mulai dari yang konvensional hingga yang lebih trategis. Definisi konvensional dari kualitas biasanya menggambarkan karakteristik sesuatu hal, seperti kinerja, kemampuan/keandalan, mudah dalam 
penggunanaan, estetika, dan sebagainya. Sedangkan dalam definisi strategis dinyatakan bahwa kualitas adalah segala sesuatu yang mampu memenuhi keinginan dan kebutuhan masyarakat. Banyak pakar dan organisasi yang mencoba mendefisikan kualitas berdasarkan sudut pandangnya masing-masing. Meskipun tidak ada definisi mengenai kualitas yang diterima secara universal dari definisi-definisi yang ada terdapat beberapa kesamaan, yaitu (a) kualitas meliputi usaha memenuhi atas melebihi harapan pelanggan (b) kualitas mencangkup produk, jasa, manusia, proses dan lingkungan (c) kualitas merupakan kondisi yang selalu berubah (misalnya apa yang dianggap merupakan kualitas saat ini mungkin dianggap kurang berkualitas pada masa mendatang). Dengan berdasarkan elemen-elemen tersebut Geostch dan Davis (1994: 9) kualitas merupakan suau kondisi dinamis yang berhubungan dengan produk, jasa, manusia, proses, dan lingkungan yang memenuhi atau melebihi harapan" (Tjiptono, 2003: 4).

Kedelapan, pengertian santri, sebutan santri biasanya selalu berhubungan dengan eksistensi tokoh agama yang lebih dikenal dengan sebutan kyai. Artinya, bila ada santri, maka tentu ada kyai yang mengajar mereka. Selanjutnya, interaksi antara kyai dengan santri biasanya melahirkan institusi pesantren. Dalam tradisi pesantren dapta ditemukan dua macam status santri, yaitu santri mukim dan santri kalong (Damopolii, 2011: 73).

Biasanya santri mukim inilah yang akan tinggal di pesantren dalam waktu yang lama. Dengan begitu, mereka memiliki kesempatan untuk menjadi pembina bagi santri-santri baru yang datang belakangan. Adapun yang dimaksud dengan santri kalong adalah mereka yang berasal dari sekeliling pesantren. Mereka ini memiliki rumah orang tua yang terletak tidak jauh dari pesantren. Dengan begitu, mobilitas mereka ke pesantren tidak ada hambatan sehingga mereka tetap tinggal di rumah milik orang tuanya (Damopolii, 2011: 73).

Menurut pengertian yang dipakai dalam lingkaran orang-orang pesantren, seorang alim hanya bisa disebut kyai bilamana memiliki pesantren dan santri yang tinggal dalam pesantren tersebut untuk mempelajari kitab-kitab Islam klasik. Macam-macam santri; (1) santri mukim yaitu santri yang berdatangan dari tempat-tempat jauh, maka ia mondok (tinggal) di asrama pondok pesantren. Sebagai santri mukim mereka memiliki kewajiban-kewajiban tertentu. (2) santri alumnus, yaitu para santri yang sudah tidak aktif tinggal di pesantren tetapi masih sering datang pada acara-acara insidental dan tertentu yang diadakan pesantren. Mereka masih memiliki komitmen hubungan dengan pesantren, terutama terhadap kyai pesantren. (3) santri kalong yaitu murid-murid yang berasal dari desa di sekeliling pesantren, yang tidak menetap di pesantren untuk mengikuti pelajarannya, mereka bolak-balik dari rumahnya sendiri. (Zamakhsari Dhofier: 51-52). (4) santri luar yaitu santri yang tidak terdaftar secara resmi di pesantren tersebut dan tidak mengikuti kegiatan rutin pesantren, sebagaimana santri mukim 
dan santri kalong, tetapi mereka memiliki hubungan batin yang kuat dan dekat dengan kyai. Sewaktu-waktu mereka mengikuti pengajian-pengajian agama yang diberikan oleh kyai dan memberikan sumbangan partisipasif yang tinggi apabila pesantren membutuhkan sesuatu (Arifin, 1993: 77 dan Usman, 1988: 109).

\section{HASIL DAN PEMBAHASAN}

Pondok pesantren selaku lembaga pendidikan, dalam mencapai tujuannya selalu tidak terlepas dari fungsi utamanya. Selain sebagai pusat pengkader Pemikiran Islam dan mencetak insan sumber daya masusia yang handal dalam hal keagamaan, namun juga berfungsi sebagai lembaga yang memiliki kekuatan untuk memberdayakan masyarakat pesantren di dalamnya (Bob, 2017: 134).

Dari hasil wawancara dengan Pimpinan Pondok Pesantren Anak Jalanan At-Tamur saat berbicara tentang sejarah berdirinya Pondok Pesantren AtTamur. Pendirian Pondok Pesantren At-Tamur tidak lepas dari berbagai permasalahan sosial, budaya, ekonomi, bahkan agama. Permasalahan yang muncul mulai dari penyimpangan-penyimpangan yang dilakukan oleh umat manusia. Pendirian pesantren At-Tamur memiliki latar belakang yang sangat unik yaitu pendirian pesantren yang memiliki singkatan "pajat" ini dari satu peristiwa yang tidak diduga-duga.

Peristiwa ini dialami oleh pendirinya sendiri manakala beliau sedang bersilaturahmi disalah satu tempat makan di kota Bandung kala itu beliau sedang bercengkrama dengan salah seorang temannya, di tengah-tengah pembicaraan mereka melihat seorang anak jalanan atau bisa dikatakan pengamen jalanan yang sedang bernyanyi menghibur para pengendara dilampu merah.

Temannya itu bertanya kepada sang pendiri pesantren, "apakah pernah melihat seorang anak jalanan mencium tangan seorang ustadz?" lalu beliau menjawab, "belum" kemudian temannya itu melontarkan pernyataan yang harus dibuktikan, ia berkata "itulah tugasmu". Berangkat dari sepenggal kisah itu, akhirnya pendirian Pondok Pesantren Anak Jalanan At-Tamur resmi didirikan pada hari minggu, 20 Januari 2008 yang beralamat di jalan Cibiruhilir No. 04 Rt 01/01 Desa Cibiruhilir, Kecamatan Cileunyi Kabupaten Bandung Jawa Barat Indonesia. Pendiri Pondok Pesantren ini diprakarsai oleh Bapak Samsudin, M. Ag, Bapak Dede Mulyadi, Bapak Drs. H. Ahmad Sabandi, dan Bapak Prof. Dr. H. Asep Muhyidin, M. Ag (Dokumen Pondok Pesantren At-Tamur).

Pesantren, merupakan lembaga pendidikan Islam yang memenuhi syarat dan ketentuan kelembagaan pesantren di Indonesia berdasarkan hasil survery administrasi kementrian agama Republik Indonesia. Pesantren di Indonesia baru dikatakan memenuhi syarat atau rukun apabila memiliki komponen-komponen didalam lingkungan pesantren tersebut. Anak, dimaksud adalah anak keturunan Nabi Adam Alaihissalam. Anak yang belajar di Pesantren At-Tamur tidak hanya anak yang berusia sebagaimana anak pada umumnya, melainkan siapa saja yang 
hendak belajar mengaji, tidak dibatasi dengan usia. Jalanan, yaitu jalan atau cara (metode) manusia dalam berusaha menjalankan (ajaran agama) atau perintah Allah SWT dan rasul-Nya yang telah disampaikan oleh ustadz, kyai dan ulama pewaris para nabi.

At-Tamur merupakan nama yang berasal dari nama Yayasan yang didirikan oleh Drs. H. Ahmad Subandi dengan memiliki arti kurma. At-Tamur dinisbatkan pada sebuah nama buah yang hidup di atas tanah tandus di daerah Timur Tengah. At-Tamur dimaknai secara filosofis yaitu pesantren yang harus tetap hidup berkembang sekalipun tidak memiliki banyak hal sebagaimana yang dimiliki oleh pesantren di Indonesia pada umumnya. Wal hasil pesantren anak jalanan At-Tamur adalah pesantren anak Adam yang sedang berjalan kembali menuju Tuhan, alasan lain diberi nama Pesantren Anak Jalanan At-Tamur adalah pesantren ini diresmikan bersama anak jalanan, anak terlantar, sopir angkot, kendek, tukang parkir, pengamen, eks narkoba, eks narapidana dan anak-anak yang bersal dari keluarga tidak mampu, baik dipandang dari sisi ekonomi maupun pendidikan agama juga pendidikan formal (Profil Pondok Pesantren AtTamur).

Pondok Pesantren At- Tamur memiliki struktur kepengurusan Pondok Pesantren At-Tamur. Kepengurusan Pondok Pesantren At-Tamur terdiri dari penasehat, pembina dan pengurus harian juga dibantu oleh pengurus kesantrian. Pengurus ini berasal dari Tokoh Masyarakat, Tokoh Agama, Tokoh Pendidikan, Ustadz dan beberapa alumni Pondok Pesantren At-Tamur, sebagaimana berikut: (a) Dewan Penasehat: Drs. H. Ahmad Subandi, Prof. Dr. H. Asep Muhyidin, MA, Dr. H. Dudang Gojali, M. Ag, Nanang Suriyana, M. Ud. (b) Dewan Pengurus: Direktur, Samsudin, M. Ag, Sekertaris Ilin Sholehudin, M. Pd. I, Bendahara Asep Malik, M. Pd, Kabag Humasy Ilham Nurjama, M. PdI. (c) Lurah Santri: Muhammad Suhendar.

Berdirinya Pondok Pesantren At-Tamur ini bertujuan tidak lain dan tidak bukan untuk memberikan kesempatan kepada anak jalanan untuk mendapatkan hak yang sama dalam hidup, yakni untuk mendapatkan ilmu pengetahuan dan yang paling penting adalah ilmu agama. Pendiri lembaga ini sebagaimana telah dipaparkan diatas memiliki tujuan untuk memberikan tempat tinggal atau sarana yang mampu memberikan hak hidup seperti tidur, makan, beribadah dan mendapatkan kelayakan dalam menuntut ilmu (Profil Pondok Pesantren AtTamur).

Pimpinan Pondok Pesantren At-Tamur Bapak Samsudin juga menjelaskan Tujuan didirikan Pondok Pesantren At-Tamur tempat singgah, dan konsultasi bagi orang-orang yang sedang menempuh perjalanan (taubat, atau memperbaiki diri) dengan menjalankan ajaran agama Islam, baik dari segi Aqidah, Ibadah, dan Akhlak (Wawancara dengan Bapak Samsudin selaku Pimpinan Pondok Pesantren At-Tamur pada tanggal 05 Juli 2019 pukul 21:30). 


\section{Estabilishing Objective (Penetapan Tujuan) Implementasi Perencanaan Pondok Pesantren Dalam Meningkatkan Kualitas Santri}

Dalam rangka meramalkan ini harus menentukan dengan tegas hasil akhir yang diinginkan. Penetapan tujuan ini merupakan tugas dari hasil pimpinan. Tujuan harus di kembangkan untuk menentukan semua kegiatan yang akan dilakukan. Dalam menyusun setiap kegiatan suatu pengelolaan waktu pelaksanaannya merupakan suatu hal yang penting bagi sebuah organisasi atau lembaga agar semua perencanaan yang diterapkan di organisasi atau suatu lembaga tersebut akan berjalan lancar sesuai apa yang telah diinginkan. Karena lembaga organisasi, lembaga pendidikan maupun perusahaan memiliki tujuan yang berbeda-beda baik dalam segi metode atau cara agar mencapai tujuan yang sudah ditetapkan pada perencanaan awal oleh setiap manajemen yang terbentuk dalam lembaga organisasi, lembaga pendidikan maupun perusahaan. Begitupun dengan Pondok Pesantren At-Tamur yang termasuk dalam lembaga pendidikan dengan tujuan utama bahwa untuk memperbaiki akhlak para pelajar, murid, ataupun santri yang sedang menjalankan kegiatan belajar untuk menuntut ilmu yang harus didapatkan dengan tujuan untuk memperbaiki akhlak agar bisa menjadi insan yang berguna bagi masyarakat, bangsa, dan agama.

Setelah wawancara dengan salah satu santri Pondok Pesantren Anak Jalanan At-Tamur menjelaskan cara Pondok Pesantren At-Tamur menurut salah satu narasumber dari kalangan santri bahwasannya memberikan kegiatan Tawasulan dan Ngobrol untuk mempertahankan tujuan awal yaitu akhlak santri dan untuk meningkatkan kualitas santri dengan ngobrol bareng antara pimpinan Pondok Pesantren At-Tamur dengan para santri yang hadir pada malam Tawasulan yaitu tepat pada setiap malam Jumat (wawancara Landi sebagai santri Pondok Pesantren At-Tamur pada tanggal 05 Juli 2019 pukul 21.00).

Dengan penetapan tujuan perencanaan juga bisa merumuskan keadaan dan pemahaman akan posisi lembaga saat ini dari tujuan yang hendak dicapai adalah sangat penting, karena tujuan dan rencana menyangkut waktu yang akan datang. Selain itu, tujuan perencanaan ini dapat di rumuskan untuk menggambarkan rencana kegiatan lebih lanjut. Pimpinan Pondok Pesantrn At-Tamur yaitu Bapak Samsudin menjelaskan tujuan Pondok Pesantren At-Tamur yang beliau pimpin bertujuan untuk meningkatkan pelajaran agama, baik dari segi akhlak, dan ibadah agar seluruh santri berkualitas dan bisa berguna bagi masyarakat yang ada di sekitar Pondok Pesantren At-Tamur (Wawancara dengan Bapak Samsudin selaku Pimpinan Pondok Pesantren At-Tamur pada tanggal 05 Juli 2019 pukul 21: 30).

Maka dari itu satu kemajuan organisasi adalah dengan adanya suatu tujuan yang dilakukan karena tujuan adalah suatu keharusan dalam setiap langkah dalam sebuah kegiatan. Tujuan juga bisa menjadi suatu pengembangan dalam sebuah 
rencana atau serangkaian kegiatan. Begitu juga di Pondok Pesantren At-Tamur untuk meningkatkan kualitas santrinya agar bisa menggapai tujuan pondok pesantren dengan mengadakan kegiatan yang berhubungan dengan perkembangan santri.

\section{Programming (Pemrograman) Implementasi Pererncanaan Pondok Pesantren dalam Meningkatkan Kualitas Santri}

Seluruh lembaga ataupun organisasi memiliki sebuah perencanaan yang sudah di tetapkan dari awal berdirinya lembaga dan organisasi tersebut yang memiliki sebuah program kegiatan untuk menghidupkan lembaga dan organisasi agar mencapai sebuah tujuan yang sudah ditetapkan dan mencapai tujuan yang diinginkan. Perencanaan harus menetapkan prosedur kegiatan-kegiatan demi tercapainya tujuan yang diinginkan. Pimpinan memperkuat langkah-langkah tindakan yang akan diambil berdasarkan prioritas pelaksanaan. Dalam eksistensinya Pondok Pesantren At-Tamur adalah salah satu lembaga yang mempunyai tujuan dan orientasi, serta menginginkan lembaganya berjalan maksimal dan mencapai tujuan secara efektif dan efisien.

Berbagai program kegiatan yang dijalankan di Pondok Pesantren AtTamur untuk memberikan kebutuhan para santrinya supaya mendapatkan ilmuilmu keislaman, mulai dari kegiatan mengaji, mengabdikan diri pada masyarakat sekitar, lingkungan dan menjaga serta melestarikan alam sekitar. Di Pondok Pesantren At-Tamur mungkin cukup berbeda dengan pesantren pada umumnya yang ada di Indonesia. Disni santri bukan hanya dituntut untuk belajar dan mengaji saja akan tetapi mengharuskan santri berperan serta dalam kegiatan masyarakat sekitar. Para santri diwajibkan untuk ikut serta dalam urusan membantu warga setiap mereka libur kegiatan kampus atau tidak memiliki kegiatan, mereka membantu membereskan rumah-rumah warga yang ada di sekitar lingkungan pesantren bagi santriwati. Program yang ada di Pondok Pesantren At-Tamur yaitu: 1) Program jangka pendek (a) Mengaji al-qur'an, hadits dan kitab kuning. (b) Praktek ibadah mahdhoh dan ghair mahdhoh. (c) Belajar akhlak, perilaku baik terhadap Allah, Rasul, orang tua, guru, sesama manusia dan alam semesta. (d) Memeberikan fasilitas (media) belajar bagi anak putus sekolah dan tidak mampu untuk mendapatkan pendidikan formal. (e) Memberikan jalan (mediasi) fasilitas belajar berupa beasiswa kepada anak yang kurang mampu agar mendapatkan pendidikan yang layak. (f) Memberikan (berbagi) rizki, ilmu dan pengalaman baik kepada anak yang membutuhkan seperti anak yatim piatu dan dhu'afa. (g) Memberikan peluang usaha dengan menyediakan pendidikan dan latihan mewirausahaan kepada santri yang sudah dewasa selanjutnya diberikan jalan untuk berusaha secara mandiri. (h) Berorganisasi yaitu memberikan peluang seluas-luasnya kepada santri agar belajar hidup bersama dalam bentuk terlibatnya pada beberapa organisasi pelajar 
dan kemasyarakatan. (i) Memberikan pembinaan atau konseling (terapi) eks narkoba dan anak yang depresi mental. 2) Program jangka panjang (a) Menfasilitasi santri dan dewan guru untuk mendapatkan beasiswa pendidikan tinggi baik dalam dan luar negeri. (b) Menfasilitasi dewan guru dan santri memiliki usaha sendiri yang mandiri. (c) Menfasilitasi dewan guru dan santri memiliki lembaga pendidikan dan pengabdian masyarakat sendiri yang mandiri.

Sebagaimana program-program yang diterapkan di Pondok Pesantren AtTamur berbagai kegiatan mereka lakukan bukan hanya mengaji dan belajar pendidikan formal atau membantu warga sekitar tetapi seluruh santri diwajibkan untuk membantu dalam memajukan kecerdasan umat Islam yaitu dengan mengajar anak-anak yang berada dilingkungan sekitar. Mengajar, mendidik, membimbing dan mengarahkan anak madrasah diniyah supaya menanamkan nilai-nilai agama sejak dini dengan tujuan dan harapan suapaya cahaya Islam tidak redup termakan zaman (Profil Pondok Pesantren At-Tamur).

Maka dari itu, pemrograman Pondok Pesantren At-Tamur mempengaruhi peningkatan kualitas santri dengan program kegiatan yang sudah direncanakan oleh pondok pesantren dengan tujuan meningkatkan kualitas ilmu pengetahuan, agama, dan sosial agar mampu memberikan manfaat kepada masyarakat baik di sekitar Pondok Pesantren At-Tamur maupun diluar wilayah Pondok Pesantren At-Tamur.

Dari hasil wawancara dengan Pimpinan Pondok Pesantren At-Tamur peneliti menangkap pernyataan beliau. Menurut pimpinan Pondok Pesantren AtTamur Bapak Samsudin, M. Ag program Pondok Pesantren At-Tamur mengadakan kegiatan mengaji ba'da isya dan mengajar ngaji ba'da magrib. Jadi, santri yang dikalangan mahasiswa wajib mengajar ngaji pada tingkatan anak-anak di waktu setelah sholat magrib dengan cara formal (Wawancara dengan Bapak Samsudin selaku Pimpinan Pondok Pesantren At-Tamur pada tanggal 05 Juli 2019 pukul 21: 30).

Secara keilmuan santri Pondok Pesantren At-Tamur sudah meningkatkan kualitas mereka dengan mengikuti program pengajian kitab kuning, mengajar di pengajian, dan dalam lingkungan perkuliahan. Dalam pemrograman diatas masuk kedalam sifat edukatif (education). Lalu ada pendidikan sosial di Pondok Pesantren At-Tamur seperti santri yang menjadi pengurus DKM (Dewan Kemakmuran Masyarakat) seluruh santri masuk kedalam struktural masyarakat sekitar Pondok Pesantren At-Tamur (Wawancara dengan Bapak Samsudin selaku Pimpinan Pondok Pesantren At-Tamur pada tanggal 05 Juli 2019 pukul 21:30). Pondok Pesantren At-Tamur juga memberikan pelatihan-pelatihan kewirausahaan yang bertujuan agar santri mampu menjadi seorang pedagang yang sukses walaupun hasil dagangan tidak di salurkan kepada Pondok Pesantren (Wawancara dengan Bapak Samsudin sebagai Pimpinan Pondok Pesantren AtTamur). 


\section{Budgeting (Penganggaran) Implementasi Perencanaan Pondok Pesantren Dalam Meningkatkan Kualitas Santri}

Lembaga maupun organisasi memiliki anggaran biaya untuk sebuah kegiatan yang akan dilaksanakan yang telah dijelaskan dalam teori Anggaran (budget) merupakan penerjemahan program ke dalam satuan numerik. Anggaran tidak akan dapat disusun dengan baik bila perusahaan tidak memiliki program yang jelas. Hal tersebut disebabkan karena setiap rupiah yang akan dikeluarkan dalam anggaran mengacu ke program yang akan dikerjakan oleh perusahaan (Ismail Sholihin, 2012:31). Pimpinan dan pengurus menetukan waktu yang tepat, karena ini merupakan suatu ciri yang penting dari suatu tindakan yang baik. Pimpinan menentukan waktu dari kegiatan-kegiatan mulai menyusun jadwal, kapan harus dimulai dan berapa lama setiap aktivitas dikerjakan.

Dari hasil wawancara dengan pimpinan Pondok Pesantren Anak Jalanan At-Tamur penganggaran kegiatan di Pondok Pesantren At-Tamur bersumber dari "Perekanan". Yang dimaksud perekanan adalah sumber dana kegiatan yang berhubungan dengan teman membantu dalam donasi penambahan biaya kegiatan yang diselenggarakan oleh Pondok Pesantren At-Tamur dan dengan dibantu oleh para santri yang menganggarkan semampu mereka untuk membantu berjalannya kegiatan yang diselenggarakan oleh Pondok Pesantren At-Tamur (Wawancara dengan Bapak Samsudin selaku Pimpinan Pondok Pesantren At-Tamur pada tanggal 05 Juli 2019 pukul 21:30).

Dan hasil wawancara dengan salah satu santri Pondok Pesantren Anak Jalanan At-Tamur menyampaikan pernyataannya bahwa Pondok Pesantren AtTamur sebelum mereka mengadakan acara pimpinan Pondok menanyakan terlebih dahulu kepada santri sanggup menyumbangkan dana berapa. Jika sudah ditentukan, maka masing-masing dari santri menambahkan dana yang telah ditetapkan dengan kesepakatan yang mereka adakan. Setelah mereka yang berjalan lebih dulu barulah mereka mengadakan hubungan antar rekan untuk menjadi sumber dana kegiatan mereka dan itu tidak di patokkan harganya hanya seiklasnya yang memberikan (wawancara Landi sebagai santri Pondok Pesantren At-Tamur pada tanggal 05 Juli 2019 pukul 21.00).

\section{Analisis Hasil Penelitian Implementasi Perenanaan Pondok Dalam Meningkatkan Kualitas Santri}

Pondok Pesantren At-Tamur merupakan sebuah lembaga yang memiliki perencanaan baik perencanaan yang tertulis maupun yang tidak tertulis. Perencanaan Pondok Pesantren At-Tamur kebanyakan tidak tertulis karena Pondok Pesantren At-Tamur bukan lembaga formal melainkan nonformal agar tetap bisa menjaga kepesantrenannya.

Perencanaan Pondok Pesantren At-Tamur dapat ditinjau dari segi objeknya bahwasannya perencanaan yang ditinjau dari segi objek membahas 
tentang perencanaan ekonomi, dan perencanaan pendidikan. Pondok Pesantren At-Tamur adalah salah satu lembaga pendidikan yang mendidik manusia baik dari umur anak-anak sampai kepada umur yang dewasa dan dengan pendidikan sosial ekonomi di Pondok Pesantren At-Tamur juga telah memberikan dampak yang positif baik dari kalangan santri maupun masyarakat sekitar.

Setelah melakukan penelitian di Pondok Pesantren At-Tamur dengan melalui berbagai langkah-langkah penelitian yang telah dilakukan mulai dari observasi kelapangan secara langsung yaitu pada Pondok Pesantren At-Tamur kemudian melakukan wawancara dengan salah satu pendiri dan santri Pondok Pesantren At-Tamur.

Berdasarkan observasi dan wawancara dengan beberapa sumber yang peneliti lakukan di Pondok Pesantren At-Tamur yang memberikan hasil bahwasannya peneliti memiliki rumusan yaitu tentang penetapan tujuan, pemrograman, dan penganggaran kegiatan Pondok Pesantren At-Tamur. Hasil penelitian sebagai berikut:

Pertama, penetapan tujuan Pondok Pesantren At-Tamur memiliki tujuan untuk meningkatkan kualitas santrinya yang berpengaruh kepada masyarakat sekitar Pondok Pesantren At-Tamur pada khususnya dan kepada umat pada umumnya. Sebab Pondok Pesantren At-Tamur bertujuan untuk meningkatkan kesuksesan santri baik dari ilmu pengetahuan maupun ilmu agama akan tetapi yang paling didahulukan yaitu ilmu agamanya karena berbasis pendidikan agama.

Tujuan Pondok Pesantren At-Tamur dengan teori tujuan yang menurut buku karya Ismail Sholihin Tujuan secara generik dapat didefinisikan sebagai hasil-hasil akhir (end results) yang ingin dicapai oleh perusahaan. Misi merupakan hasil akhir yang ingin dicapai perusahaan dan memiliki horizon waktu yang sangat panjang untuk mencapainya. Selain itu misi perusahaan dinyatakan secara kualitatif lebih menunjukkan sifat (the nature of things) dari pada ukuran (the measure of thins). Berbeda dengan misi, tujuan (objective) merupakan hasil akhir yang ingin dicapai perusahaan dalam jangka waktu tertentu dan dinyatakan secara kuantitatif. Tujuan yang baik memiliki kriteria-kriteria tersendiri (Sholihin, 2012: 23).

Menurut Lumpkin dan Taylor (Sholihin, 2012: 23) tujuan yang baik memiliki kriteria-kriteria sebagai berikut: (1) Dapat diukur (Measurable). Tujuan harus dapat diukur. Untuk dapat mengukur pencapaian tujuan, sekurangkurangnya terdapat satu indikator yang dapat dijadikan rujukan untuk melihat kemajuan pencapaian tujuan. (2) Spesifik (Specific). Tujuan secara spesifik harus menjelaskan apa yang ingin dicapai oleh perusahaan. (3) Sesuai (Appropriate). Tujuan yang ingin dicapai perusahaan harus sesuai dengan visi dan misi yang dimiliki oleh perusahaan, artinya tujuan yang ingin dicapai masih berada dalam lingkup misi perusahaan. (4) Realistis (Realistic). Tujuan yang dibuat oleh perusahaan harus dapat dicapai dengan menggunakan sumber daya organisasi 
yang dimiliki perusahaan. (5) Tepat waktu (Timely). Perusahaan harus menetapkan secara spesifik berapa lama jangka waktu yang dibutuhkan perusahaan untuk mencapai tujuan yang telah ditetapkan (Sholihin, 2012: 23).

Berdasarkan Teori tujuan Pondok Pesantren At-Tamur sangat relavan dengan teori menurut Lumpkin dan Tylor karena tujuan Pondok Pesantren AtTamur dapat diukur sampai dimana kualitas santri, spesifik, sesuai dengan tujuan Pondok Pesantren At-Tamur dan realistis maka dari itu menurut peneliti tujuan Pondok Pesantren At-Tamur sangat relavan dengan teori Lumpkin dan Tylor. Maka dari itu, tujuan Pondok Pesantren At-Tamur sudah memenuhi kriteriakriteria tujuan yang telah dipaparkan diatas menurut Lumpkin dan Tylor yang ditulis dalam karangan Ismail Sholihin. Dengan tujuan yang sudah ditetapkan oleh pimpinan maka tujuan untuk meningkatkan kualitas santri akan berjalan dengan bimbingan para asatidz dan pimpinan Pondok Pesantren At-Tamur sendiri.

Kedua, pemrograman kegiatan, tentang pemrograman kegiatan di Pondok Pesantren At-Tamur memiliki program jangka pendek dan jangka panjang. Program Pondok Pesantren At-Tamur adalah rencana konkret dalam program yang sudah tercantum baik sasaran dan kebijakan pondok pesantren dalam membangun kualitas santri agar bisa bermanfaat bagi masyarakat sekitar.

Dengan hasil penelitian yang dilakukan dengan menggunakan metode observasi dan wawancara di Pondok Pesantren At-Tamur bahwa Pondok Pesantren At-Tamur memiliki program-program kegiatan yang tidak tertulis, karena selagi program tersebut bermanfaat buat menambah kualitas santri maka program tersebut akan tetap di jalankan seperti bersosialisasi kepada masyarakat dan ikut serta dalam organisasi masyarakat dan dengan begitu para santri akan mandiri untuk mengabdi kepada pondok pesantren yang menjadikan tempat tinggal para santri sebagai rumah kedua. Dijelaskan bahwa suatu rencana biasanya meliputi bidang-bidang produksi, finansial, personalia dan pemasaran yang masing-masing disusun dalam berbagai program dan setiap program ini harus saling menunjang pelaksanaan berbagai macam program itu. Programming adalah proses penyusunan suatu program, jadi programming sifatnya dinamis sedangkan program sifatnya statis (Hasibuan, 2006: 95).

Di suatu instansi, perusahaan maupun lembaga program menjadikan inti untuk menghidupkan kegiatan yang ada dalam perusahaan, lembaga atuapun suatu instasnsi agar mampu mencapai suatu tujuan yang sudah di tetapkan. Program merupakan serangkaian kegiatan yang memiliki durasi waktu tertentu serta dibuat untuk mendukung tercapainya tujuan perusahaan. Sebagai sebuah aktivitas yang memiliki durasi waktu tertentu. Program memiliki waktu mulai dan waktu selesai (Sholihin, 2012:31).

Pondok Pesantren At-Tamur memiliki 2 program yaitu program jangka panjang dan program jangka pendek. Masing-masing dilaksanakan tentu guna 
untuk meningkatkan kualitas santrinya agar bisa bermanfaat bagi masyarakat sekitar dan membuat santri lebih mandiri untuk mengabdi kepada pesantren dan masyarakat sekitar. .

Ketiga, penganggaran kegiatan, penganggaran merupakan hal yang utama untuk menjalankan sebuah program agar bisa berjalan dengan apa yang diinginkan. Penganggaran kegiatan Pondok Pesantren At-Tamur bersumber dari rekanan atau yang disebut sahabat. Sumber anggaran kegiatan Pondok Pesantren At-Tamur ini dilakukan dengan pendekatan sosial yang sering disebut bantuan atau sumbangan. Penganggaran kegiatan di Pondok Pesantren At-Tamur dimulai dari santrinya terlebih dahulu sebelum dari rekan masing-masing. Jika ditinjau dari teori penganggaran Pondok Pesantren At-Tamur ini belum memiliki yang nama nya master budget dan capital budget dari teori Simth di buku Ismail Sholihin karena penganggaran di Pondok Pesantren At-Tamur hanya di dukung oleh para rekan yang mau menyumbangkan dananya kepada Pondok Pesantren At-Tamur apabila mengadakan sebuah kegiatan.

Dari hasil penelitan yang dilakukan dengan wawancara dan observasi kelapangan peneliti mengambil kesimpulan bahwasannya Pondok Pesantren AtTamur dalam penganggaran sangatlah terbatas hanya mengandalkan masukan dana dari para santri dan para sahabat-sahabat atau kerabat yang ingin menyumbangkan dana dengan lingkungan yang terbatas dan santri yang tidak tahu berapa jumlahnya pimpinan pondok hanya dengan meyakinkan para kerabat dan sahabat untuk membantu mereka dalam menambahkan dana yang diperlukan untuk mengadakan kegiatan. Dengan bertujuan meningkatkan kualitas para santri nya agar lebih menjadi orang yang disimplin dan dapat berguna bagi masyarakat sekitar dan lainnya.

\section{PENUTUP}

Dari hasil kajian atas data-data penelitian, maka dapat diambil kesimpulan bahwa: (1) Penetapan tujuan Pondok Pesantren At-Tamur di tentukan langsung oleh Pimpinan Pondok Pesantren. Pengaplikasian untuk mencapai tujuan pondok pesantren dilakukan oleh santri Pondok Pesantren At-Tamur dalam menentukan rencana-rencana pondok pesantren dalam meningkatkan kualitas santrinya. Maka dari itu, pengaplikasian dilakukan oleh santri agar para santri bisa berkembang secara mandiri dengan ikut sertanya kepada masyarakat sekitar agar lebih bermanfaat. Dengan tujuan pondok pesantren yang sudah di tentukan oleh pimpinan pondok pesantren yang harus dilakukan dan didukung dengan kegiatan-kegiatan agar tetap mempertahankan tujuan awal Pondok Pesantren AtTamur supaya seluruh santri Pondok Pesantren At-Tamur memiliki kualitas yang bermanfaat bagi masyarakat sekitar karena kesuksesan santri di ukur dengan manfaatnya santri di masyarakat atau tidak manfaatnya di masyarakat. (2) Dalam melakukan aktivitas kegiatan tentunya setiap lembaga maupun organisasi 
memiliki program kegiatan agar mendukung untuk mecapainya sebuah tujuan yang diinginkan. Pondok Pesantren At-Tamur memiliki program utama yaitu program jangka panjang dan program jangka pendek. Masing-masing dilaksanakan tentu guna untuk meningkatkan kualitas santrinya agar bisa bermanfaat bagi masyarakat sekitar. (3) Anggaran atau biaya kegiatan Pondok Pesantren At-Tamur bersumber dari para rekan dan para santrinya sendiri karena setiap mengadakan kegiatan besar seperti berbasisi pelatihan kewirausahaan yang memerlukan dana yang besar maka Pondok Pesantren AtTamur hanya memungut seiklasnya dari para santri dan para rekan-rekan yang ingin menyumbangkan atau membantu dalam berjalannya kegiatan yang telah direncanakan.

Perencanaan Pondok Pesantren At-Tamur yang telah dirumuskan oleh Pimpinan Pondok Pesantren At-Tamur oleh Bapak Samsudin tentang perencaan Pondok Pesantren At-Tamur dalam mendidik dan meningkatkan kualitas santrinya agar bisa berguna bagi masyarakat sekitar khususnya dan kepada bangsa dan agama pada umumnya. Dengan memberikan program-program kegiatan dan arahan agar santri tetap bisa menuntut ilmu agama, pendidikan, sosial dan lain sebagainya. Oleh karena itu, Pondok Pesantren At-Tamur memberikan wadah kepada anak jalanan yang mau menuntut ilmu dan yang mau kembali kepada jalan Tuhan.

Beranjak dari kesimpulan di atas, maka ada beberapa saran yang ingin disampaikan oleh peneliti guna untuk memperbaiki masa yang akan datang. Diantaranya: (1) Hendaknya Pondok Pesantren At-Tamur dapat meningkatkan keadministrasian pondok pesantren agar memiliki dokumen-dokumen yang lengkap dan mudah untuk diketahui masyarakat luas. (2) Pondok Pesantren AtTamur merupakan pondok pesantren yang memiliki progres yang sangat bagus untuk lembaga pondok pesantren, maka dari itu Pondok Pesantren At-Tamur hendaknya memberitahukan program-program, struktur, dan data-data yang tertulis agar mempermudah bagi masyarakat unutk mengetahui organisasi, program dan jumlah santri yang ada di Pondok Pesantren At-Tamur. (3) Untuk Pondok Pesantren At-Tamur untuk membangun kerja sama dengan lembaga lain agar penganggaran dalam setiap kegiatan akan lebih permudah dikarenakan adanya anggaran yang cukup untuk menjalankan kegiatan-kegiatan yang ada dalam perencanaan program Pondok Pesantren At-Tamur.

\section{DAFTAR PUSTAKA}

Alkhairy, (2017). Peran Pimpinan Pondok Pesantren Dalam Meningkatkan Kualitas Dakwah Santri. Anida (Aktualisasi Nuansa Ilmu Dakwah): Academic Journal for Homiletic Studies [Online], 11.1 (2017): 57-73. Web. 20 Nov. 2019 
E. R. Cahyono, Aliyudin, Herman

Ali, Y. (2013). Pengertian Implementasi Menurut Beberapa Abli, diakses 25 Juli 2018 dari http://rimaru.web.id/pengertian-implementasi-menurut-beberapaahli/.

Arifin, M. (1993). Filsafat Pendidikan Islam, Jakarta: Bumi Aksara cet. III

Bob, A. (2017). Manajemen Komunikasi Entrepreneur Usaha Mikro Berbasis Pondok Pesantren. Ilmu Dakwah: Academic Journal for Homiletic Studies [Online], 11.1 (2017): 133-150. Web. 20 Nov. 2019

Damopolii, M. (2011). Pesantren Modern IMMIM Pencetak Muslim Modern 1 cet 1 Jakarta: Rajawali Pers

Dhofier, Z. (1994). Tradisi pesantren: Studi tentang Pandangan Hidup Kyai Jakarta: LP3ES

Hasibuan, M.S.P. (2006). Manajemen Dasar, Pengertian, dan Masalah, Jakarta: Bumi Aksara

Solihin, I. (2012). Manajemen Strategik. Jakarta: Erlangga

Susilawati, I. (2016). Implementasi Fungsi Manajemen dalam Pelayanan Bimbingan Manasik Haji di Kelompok Bimbingan Ibadah Haji. Tadbir Journal Manajemen Dakwah: Academic Journal for Homiletic Studies [Online], 11.1 (2016): 190-206. Web.20 Nov. 2019

Tjiptono, Fandy dan Anastasia D. (2003) Total Quality Management. Yogyakarta: Andi Offiset

Widjajakusuma, M. K. (2002) Pengantar Manajemen Syariat Jakarta: Khoirul Bayan

Dokumen Pondok Pesantren Anak Jalanan At-Tamur. 